\title{
A Primer on Exporting to the Dominican Republic ${ }^{1}$
}

\author{
Christina D. Storz, Timothy G. Taylor, and Gary F. Fairchild ${ }^{2}$
}

\section{Introduction}

Every year the U.S. Department of State publishes extensive Country Commercial Guides for a large number of countries. These guides provide a great deal of information useful to individuals interested in developing export markets either through direct exports or through direct foreign investment. This paper provides an abridged version of the Country Commercial Guide for the Dominican Republic as well as supplemental information of direct relevance to agribusiness firms. It is hoped that the information contained in this report will provide a useful starting point for individuals interested in exploring export or investment opportunities in the Dominican Republic.

Note: County Commercial Guides are available for U.S. exporters from the National Trade Data Bank's CD-ROM or via the Internet. Please contact Stat-USA by telephone (1-800) STAT-USA for more information. Country Commercial Guides can be accessed via the World Wide Web at http://www.stat-usa.gov, http://www.state.gov, and http://www.mac.doc.gov. They can also be ordered as a hard copy or on diskette from the National Technical Information Service (NTIS) by telephone (1-800) 553-NTIS. American exporters seeking general export information/assistance and country-specific commercial information should contact the U.S. Department of Commerce, Trade Information Center by telephone (1-800) USA-TRADE; or by fax (202) 482-4473.

\section{Economic and Political Overview}

The Dominican Republic, about the size of Hawaii, occupies the eastern two-thirds of the island of Hispanola, which it shares with Haiti. As the largest democratic country in the Caribbean, it has a GDP (Gross Domestic Product) of more than US\$20 billion and is the fifth largest importer of U.S. goods in the Western Hemisphere. The country is home to almost nine million people with a per capita income of about US\$2,387. The United States is a vital economic and cultural partner of the Dominican Republic.

The Dominican economic growth rate was $4.1 \%$ in 2002 , up from $2.4 \%$ in 2001 . This growth rate was largely due to increased government spending. The economy grew another $1.5 \%$ in 2003 , which was more than offset by economic setbacks related to the collapse of Banco. The expected accumulated inflation rate for 2003 was $35 \%$.

1. This is EDIS document FE510, a publication of the Department of Food and Resource Economics, Florida Cooperative Extension Service, Institute of Food and Agricultural Sciences, University of Florida, Gainesville, FL. Published February 2005. Please visit the EDIS website at http://edis.ifas.ufl.edu.

2. Christina D. Storz, Research Assistant; Timothy G. Taylor, Professor; and Gary F. Fairchild, Professor, Department of Food and Resource Economics, Florida Cooperative Extension Service, Institute of Food and Agricultural Sciences, University of Florida, Gainesville, FL. 
The full impact of the Baninter collapse remains to be seen. Present estimates indicate a loss of more than US $\$ 2$ billion. The government's willingness and ability to deal effectively with this matter will greatly impact the future investment climate. An IMF stand-by agreement for approximately US $\$ 690$ million was signed in 2003. It is designed to help restore macroeconomic stability and to improve regulation and supervision of the banking sector. Once fully implemented, it should restore confidence in the sector.

The Dominican government has set the end goal for its economic policy to be macroeconomic stability. Thus, the present administration abolished the fuel differential tax, instituted a floating exchange rate, and implemented a new tax package to increase compliance and to simplify import duties. The Dominican exchange system is divided among the private sector and the public sector, but new policies have decreased the spread to less than $1 \%$. The average exchange rate for 2002 was DR $\$ 18$ to US\$1.

Telecommunications was the strongest individual sector in 2002, with real growth of $17.4 \%$. The electricity, government, financial, and construction sectors also remain growth sectors. Foreign investment in tourism was up more than $25 \%$ in 2002. However, the agricultural sector declined $2 \%$ in 2002, due partly to competition from imports.

Most Dominican tariffs now range from 3\% to $20 \%$, with an average import tariff of $10.7 \%$, as the government has lowered tariff rates to comply with the terms of new free trade agreements. Thus, imports to the Dominican Republic have increased over the last few years as the import regime has loosened.

The government has fully implemented most Uruguay Round obligations, although certain aspects of implementation are proceeding slowly, such as protections for intellectual property. A complex system of licensing and consular approval of invoices impedes imports. While many formal non-tariff barriers have been abolished, reports of corruption and poor organization at the ports are additional impediments to trade.
The success of free trade zones demonstrates the ability of the country to compete in global markets when trade obstacles are reduced. There is growing concern, however, about competition from Asia and the impact of the January 2005 elimination of textile quotas. Free trade zones in the Dominican Republic are allowed by law to sell $20 \%$ of their output domestically, and although this has not been implemented in the past, some companies are beginning to sell free zone products locally.

\section{Marketing U.S. Products and Services}

There are a number of factors that should be considered in exporting products to the Dominican Republic. This section provides a brief overview of many critical factors that must be considered.

\section{Distribution / Sales Channels}

There are several methods for U.S. exporters to enter the Dominican market. One can use locally appointed distributors, a wholly owned subsidiary, joint venture partners, or Dominican importers and wholesalers who also own retail outlets. A distribution agreement is not required for any of the above.

\section{Agents / Distributors: Finding a Partner}

Although the use of an agent or distributor is not required, it is frequently the best policy. A strong local representative can place products and generate sales that otherwise may not materialize. Also, laws governing and protecting Dominican agents/distributors are complicated. The U.S. Department of Commerce's Foreign Commercial Service (USFCS) at the the U.S. Embassy in Santo Domingo can help U.S. exporters find agents and distributors through several business facilitation services and research reports (e.g., single company promotion, flexible market research, mass mailing lists, market entry issues, market size, market trends, regulatory issues, competition, international company profile, international partner search, and gold key matching service). These services range in price from US\$50 to US\$750. Information on these services is located online at http://www.BuyUSA.gov/caribbean. nother useful source is Expo USA, which is an annual 
exhibition of new-to-market U.S. firms seeking agents, representatives, distributors, licensees and franchises in the Dominican Republic. Please contact the U.S. Commercial Service for additional information.

\section{Direct Marketing}

Direct marketing has met with some success for low-cost, locally produced services. Avon, Jafra, and Amway have established successful direct marketing organizations.

\section{Franchising}

After several years of continuous growth, the franchising sector has slowed down in the Dominican Republic. Restaurant franchises include Wendy's, Domino's Pizza, McDonald's, Burger King, Friday's, Baskin-Robbins, KFC, Taco Bell, Mrs. Field's, TCBY, Dairy Queen, and Tony Roma's.

\section{Joint Ventures / Licensing}

There is considerable joint venture/licensing activity in the Dominican Republic, including manufacturing and services. The foreign investment law provides for opportunities in this area. Before negotiating a joint venture or licensing partnership, legal counsel should be consulted to minimize potential conflicts, unexpected taxes, withholding expenses on royalties, contributions to capital, and related aspects of these ventures.

\section{Selling Factors / Techniques}

At the retail sales level, Dominicans prefer actually seeing the product and expect reliable after-sales service. Quality and responsiveness in after-sales service are becoming increasingly important ingredients in effective marketing strategies. In sales of services and manufactured goods, Dominicans often rely on networking, as well as close family and personal relationships. These characteristics in turn create the need for local agents and distributors or direct, in-country operations to make and sustain these contacts.

\section{Advertising / Trade Promotion}

Most businesses in the Dominican Republic use major local newspapers, television channels and radio stations to advertise their products. Because of high illiteracy rates, television and radio are the media most used for products intended to be marketed to all social classes. Companies already in the Dominican Republic are well aware of the benefits of participating in local exhibition/trade promotion shows; there are many industry specific expositions flourishing in the Dominican Republic.

\section{Sales Service / Customer Support}

Dominican customers have increasingly demanded consistent quality support and service. Service and customer support are still a developing concept. Several (both wholesale and retail) companies maintain sales volumes without discounting. This is partly attributable to the good reputation for quality service and support, which suggests the importance of after-sales support.

\section{Product Pricing}

This is a price-sensitive market where the price is often equally important as quality and service, if not more. Dominicans are often familiar with U.S. pricing practices. Many successful new retail outlets, however, concentrate on quality goods and service support as Dominican consumers become more affluent and sophisticated.

\section{Selling to the Government}

Dominican Law No. 322 of 1981 states that foreign individuals or firms must be associated with Dominican or "mixed capital" enterprises in order to bid on or execute Dominican government-funded projects. There are exceptions, and variations on levels of participation required for complex projects and many direct opportunities for foreign bidders exist when project financing is from multilateral banks or feign government aid sources, and where the bidding process is open and transparent and payment is guaranteed by outside sources.

The Mejia Administration has tried to establish a more favorable credit reputation and resolve some of the systematic problems affecting irregularities in 
public contracting in the Dominican Republic.

Several unresolved payment disputes from former Administrations remain.

\section{IPR Infringement Protection}

To ensure protection of patents and trademarks, the products must be registered at the National Office for Intellectual Property Rights of the Secretariat of State for Industry and Commerce (Oficina Nacional de Propiedad Intelectual, or ONAPI).

For protection of copyrights, U.S. firms must contact the National Office for Copyright (Oficina Nacional de Derecho de Autor of the Secretariat of State for Culture, or ONDA).

The Dominican Republic is a member of the World Trade Organization (WTO) and signatory of both the Berne and Paris Conventions on Copyrights and Patents and Trademarks, respectively. Nevertheless, protection of intellectual property rights is still weak. Even where the law provides protection, enforcement and remedies are often inadequate.

The U.S. government recognizes some improvement in efforts to improve the intellectual property rights regime. Law 65-00 on copyrights was implemented in August of 2000 and provides for strong protection of copyrighted materials; March 2003 regulatory changes to Patent Law 20-00 appear to be compliant with WTO Trade Related Aspects of Intellectual Property Rights (TRIPS) standards. Although the Dominican government has stepped up efforts in some areas, IPR enforcement generally remains inadequate, in part due to lengthy judicial processes.

\section{Need for a Local Attorney}

A local attorney is an important vehicle for establishing operations and advising on the conditions for doing business in the Dominican Republic.

\section{Agribusiness Industry Prospects}

Wheat

The largest wheat mill in the Dominican Republic was privatized in 1999 and acquired by the Central American group in 2002. Since then, it has been operating more effectively and is already paying dividends. This has translated into more wheat imports from the United States (exceeded US $\$ 45$ million in 2002).

\section{Soybean Meal}

The Dominican Republic's primary supplier of soybean meal is the United States. Soybean meal is used mainly in poultry and swine feed formulations. The market for this commodity is dependent on the poultry industry, which consumes about $70 \%$ of all feed ingredient imports. Imports of high protein soybean meal from the United States reached almost US\$70 million in 2002 .

\section{Corn}

Corn in the Dominican Republic is mostly used in feed formulations for poultry and swine. The return to acceptable price levels of corn has stimulated the use of good quality U.S. grain, lowering the local prices of poultry meat and increasing producer margins. Consumption levels have continued to increase. The direct purchase from principal producers of swine and poultry along with the merger of all main feed manufacturing companies into one (PROTEINAL) has assured continued use of corn from the United States. Corn exports in 2002 reached a record high of 1,037,000 metric tones (mt) and were valued at US\$112 million, over $10 \%$ higher in value than in the previous year.

\section{Trade Regulations and Standards}

\section{Trade Barriers}

Taxes and duties for imported goods are calculated using the ad-valorem price (i.e., CIF price in U.S. dollars multiplied by the unified foreign exchange rate). All duties and taxes are collected in Dominican pesos. There are generally three taxes on imports, except for those subject to exemptions provided by law. The taxes are: 
- Tariff (Arancel): the basic import tax, ranging from $0 \%$ to $20 \%$.

- Luxury Tax (Impuesto Selectivo al Consumo): a consumption tax for luxury imports or "non-essential" goods, ranging between $15 \%$ and $60 \%$, and calculated on the CIF price (includes perfume, whiskey, motor vehicles, and tobacco).

- Exchange Surcharge (Recargo Cambiario): a $4.75 \%$ tax imposed on all imports into the Dominican Republic.

- Industrialized Goods and Services Tax (Impuesto de Transferencia a los Bienes Industrializados y Servicios, or ITBIS): a $12 \%$ tax on processed agricultural goods and all non-agricultural goods, and services, calculated on the CIF price plus the amount paid for all taxes and duties previously mentioned.

In mid-2003, the Dominican government announced a new temporary tax of $2 \%$ on all products entering the country.

\section{Customs Valuation}

The Dominican Customs Office began to apply the GATT (General Agreement on Tariffs and Trade) valuation system as of July 1, 2001. All imported goods from WTO-member countries are now taxed taking into consideration the value indicated in the commercial invoice, excluding 31 items authorized by the WTO. These products have to pay the import tax as per a minimum value assigned by the Dominican Customs, not as listed on the commercial invoice.

Customs officials indicate that the average duration of entry takes three days from submission of complete documentation. Clearances can be made in hours if importers make use of one of the following express clearance procedures:

- Advanced Declaration (Declaracion Anticipada): Importers submit Customs documentation 25 days prior to shipment arrival.

- Express Dispatch (Despacho Expreso): Goods are declared in advance and Customs officials verify the shipment at the importer's warehouse.
Shipments may be dispatched in four hours when using this option.

\section{Standards}

The Dominican Republic tends to follow U.S. standards and requirements.

\section{Labeling Requirements}

Customs officials state that products meeting U.S. labeling and marking standards should not have any difficulty complying with relevant Dominican regulations.

\section{Temporary Entry Provisions}

There are no provisions for the temporary entry of agricultural goods. However, agricultural commodities and food products may be imported under bonded warehousing and for transshipment.

\section{Import Controls}

For the agriculture sector, "no objection" and other types of permits are often required to import agricultural commodities into the Dominican Republic. Additionally, absorption requirements are required for some agricultural commodities. Phytosanitary certificates, issued by recognized authorities in the country of origin, must accompany live plants and agricultural material used in planting. Imports of animals normally require certificates of origin and other veterinarian documentation to assure disease-free status. Testing is done at the port of entry to reconfirm pest free status. Tariff rate quotas (TRQs) were proposed for eight agricultural goods (rice, sugar, chicken parts, pork, corn, onions, milk powder, and garlic). Other products that often encounter non-tariff barriers are poultry and dairy products. Imports of food and agricultural products are normally facilitated through local distributors. Unless otherwise indicated, the Dominican Republic tends to follow U.S. standards concerning chemical tolerances in foods, packaging, and labeling requirements.

For all imports into the Dominican Republic, other than free zone imports, a consular invoice is required from a Dominican overseas consulate approving the transaction. Many U.S. exporters 
complain that fees are rarely nominal and are arbitrarily assessed, creating uncertainty regarding costs for shipments to the Dominican Republic. There is an exception for shipments from countries where there is not a Dominican Consulate.

Free trade zone imports destined for re-export are excused from this and other Customs requirements (e.g., registration requirements, import licenses, and payment of Customs duties based on commercial invoices and airway bills of lading).

There are few prohibitions on imports, although discretionary import licenses are often required from the Secretariat of Agriculture for agricultural products perceived to impede domestic production.

\section{Export Controls}

The Dominican Center for Export Promotion (CEDOPEX) uses a form to declare exports; values are reported in U.S. dollars.

\section{Free Trade Zones / Warehouses}

Free Zone Operators (FZO) and enterprises are entitled to $100 \%$ exemption for extended periods of time from all duties, taxes, charges, and fees affecting production and export activities.

\section{Membership in Free Trade Agreements}

The Dominican Republic is a member of the World Trade Organization (WTO), Central American-Dominican Republic Free Trade Area, and the Caribbean Common Market (CARICOM). At the Summit of Americas in 2001, the Dominican government committed itself to joining with other Western Hemisphere governments in completing the negotiation and implementation of a free trade agreement for the hemisphere by 2005 . Negotiations for a Free Trade Agreement with the United States began in 2003 to associate the Dominican Republic with the Central American Free Trade Agreement (CAFTA).

\section{Investment Climate in Brief}

- The Dominican government welcomes foreign investment.
- The Office for Investment Promotion (OPI) has proven to be an important contact for potential investors.

- No limits on foreign control or screening of foreign investment have been reported.

- A private sector exchange rate system is used for most commercial banking transactions.

- Dominican expropriation standards have historically been at variance with international norms. A number of U.S. investors have outstanding disputes with the Dominican government concerning expropriated land. In some cases these claims have existed for many years. Investors and lenders often have not received prompt or adequate payment. Even when compensation has been ordered by a Dominican court, or when the government has recognized the claim, actual payment has been extremely difficult to obtain.

- American firms, obliged to respect the U.S. Foreign Corrupt Practices Act, have had particular difficulty accessing justice with the Dominican system and defending their interests in court. Recent judicial reforms and pending legislation have somewhat improved the administration of justice in the country, but judicial procedures are of uneven quality. In 2002, the Dominican Republic became a member of the International Center for the Settlement of Investment Disputes (ICSID, a.k.a. the "Washington Convention") and ratified the 1958 New York Convention on Arbitral Awards, thereby recognizing the right of companies to pursue international arbitration.

- No special investment incentives or other forms of favored treatment are given to foreign investors.

- Secured interests in both movable and real property are recognized and generally respected.

- In an effort to improve the transparency and effectiveness of the laws affecting competition, the government has carried out a major reform effort. Customs regulations and major 
components of the tax laws and labor code have been reformed.

- Despite strong GDP growth and successful reform efforts that, until recently, combined to produce a relatively healthy financial sector, Dominican authorities failed to detect years of large-scale fraud and mismanagement at Baninter (the country's third largest bank).

- Although Dominican law prohibits governmental corruption, it remains a pervasive problem throughout the executive, judicial, and legislative branches at all levels of the government and within law enforcement agencies nationwide.

- No bilateral investment agreement exists between the Dominican Republic and the United States.

- The Overseas Private Investment Corporation (OPIC) is active in the Dominican Republic with both loan and insurance programs.

- There is an adequate labor supply, but there is a lack of skilled workers and technical supervisors. Most employers report the local work force as trainable, competent, and cooperative.

- In the last few years, foreign direct investment has been concentrated primarily in tourism, electricity generations, communications, and free trade zone activity. The decision to privatize suffering state enterprises (e.g., sugar, airport management, and electricity) has attracted foreign investment to these sectors.

\section{Business Customs}

\section{Travel Advisory and Visas}

Travelers are encouraged to read the Consular Information and Background Notes for the Dominican Republic located on the U.S. Department of State's website. There are currently no travel warnings specifically for the Dominican Republic, but for the most up-to-date travel information, check the U.S. Department of State's website (http://www.state.gov), or telephone toll-free
(1-888) 407-4747.

\section{Business Infrastructure}

Private sector business hours are typically 8:00 a.m. to 5:00 p.m., Monday through Friday. Some companies work Saturday morning. Government office hours are 7:30 a.m. to 2:30 p.m., Monday through Friday. Lunch hours are usually from 12:00 p.m. to 1:00 p.m. or 1:00 p.m. to 2:00 p.m.

Lunch meetings are common and breakfast meetings are becoming more frequent, especially among firms operating internationally. Appointments are generally required, but punctuality is not a consistent business practice. Most Dominican business people speak English, but communication in Spanish is more prevalent. Business cards are exchanged.

The Dominican Republic has a well-developed road network, which is continuously being improved. However, as in most developing countries, some roads and highways are in poor condition.

There are seven international airports in the Dominican Republic: Santo Domingo (2), La Romana, Puerto Plata, Punta Cana, Samana, Santiago, and Barahona. Additional airports in Santiago and Monte Cristi are planned, but not yet built.

Santo Domingo and other major cities have modern port facilities. Transportation to more than a dozen U.S. ports is available on a weekly basis. Daily freight service to Puerto Rico is also available.

The Dominican Republic has one of the most progressive telecommunications networks in Latin America, including direct distance dialing, international direct distance dialing, electronic mail, line 800, telnet, fax, cellular mobile phones, national paging service, and Internet service.

\section{Useful Web Sites}

\section{DOMINICAN REPUBLIC:}

- American Chamber of Commerce of the Dominican Republic http://www.amcham.org.do 
- A Lawyer's Guide to the Dominican Republic http://www.natlaw.com/pubs/spdrga1.htm

- National Statistics Office http://one.gov.do

\section{UNITED STATES:}

- USDA Foreign Agricultural Service

http://www.fas.usda.gov

- US Export Programs Guide http://infoserv2.ita.doc.gov/ticwebsite/tic.nsf/

AF34FA880278BDD5825690D00656C6F/

F69FDCF72B7713B58525691900746F18?Open

Document

- Internet Guide to Trade Leads

http://infoserv2.ita.doc/gov/ticwebsite/tic.nsf/

504ca249c786e20f85256284006da7ab/

ef7db94aef24919885266470049c1cd?OpenDocu

ment

- US Trade Finance Resources

http://infoserv2.ita.doc.gov/ticwebsite/tic.nsf/

AF34FA880278BDD5825690D00656C6F/

F69FDCF72B7713B58525691900746F18?Open

Document

- Basic Guide to Exporting

http://www.unzco.com/basicguide/index.html

\section{HEMISPHERIC:}

- Hemispheric Guide on Customs Procedures http://alca-ftaa.iadb.org/hgcp_eng.htm

- Hemispheric Trade and Tariff Database http://alca-ftaa.iadb.org/eng/ngmadb_e.htm 